\title{
Investigating the Effect of Dividend Policy on the Wealth of Stockholders of Listed Companies on the Ghana Stock Exchange
}

\author{
Evans Fayol Nkuah ${ }^{1} \&$ Hadrat Yusif $^{2}$ \\ ${ }^{1}$ Institute of Distance Learning, Kwame Nkrumah University of Science \& Technology, Kumasi, Ghana \\ ${ }^{2}$ Department of Economics, Kwame Nkrumah University of Science \& Technology, Kumasi, Ghana \\ Correspondence: Evans Fayol Nkuah, Institute of Distance Learning, Kwame Nkrumah University of Science \& \\ Technology, Kumasi, Ghana. Tel: 020-414-3581. E-mail: penfayol@yahoo.com
}

Received: March 27, 2016

Accepted: April 29, 2016

Online Published: June 25, 2016

doi:10.5539/ijef.v8n7p47

URL: http://dx.doi.org/10.5539/ijef.v8n7p47

\begin{abstract}
This paper has examined the impact of dividend policy on the wealth of stockholders of selected registered companies on the Ghana Stock Exchange (GSE). Secondary data were collected on 25 listed firms using annual reports from 2005 to 2011. The dependent variable was wealth of stockholders proxied by market price per stock. The explanatory variables included dividend per stock (DPS), retained earning per stock (REPS), financial leverage (FLEV), and price earning ratio (PER). Fixed-effect model was fitted to the data. The regression results showed that dividend payment, retained earning, and price earning ratio have significant positive impact on the stock market price. It was also found that the impact of dividend is more pronounced than that of retained earning in the context of companies registered on the Ghana Stock Exchange. It is therefore recommended that optimal trade-off between dividend payment and retained earning be established by corporate management to maximise the wealth of stockholders.
\end{abstract}

Keywords: dividend policy, stock market price, stockholders, Ghana stock exchange

\section{Introduction}

To improve the wealth of stockholders and maximize corporate profits, corporate management formulates different financial policies for the corporation. These policies may be grouped into three i.e. investment policy, financing policy, and dividend policy. Of these three policies, dividend policy is central because it influences financing policy and financing policy in turn influences the choice of investment policy.

Since the 1950s the debate on the impact of dividend policy on stock market price has triggered many studies on the impact of dividend policy on stockholders value. Yet, the results are not conclusive. Some of the studies have reported that dividend policy has no influence on the wealth creation of stockholders (Uddin \& Chowdhury, 2005; Adefila, Oladapo, \& Adeoti; 2013). Others studies have also argued that dividend policy has impact on the wealth of stockholders (Khan, 2009; Salih, 2010; Joshi, 2011; Mohammad, 2013).

In the Ghanaian context, few studies have been conducted on dividend policy. A study by Amidu in 2007 reported that dividend policy has positive influence on the performance of firms listed on the Ghana Stock Exchange. Agyei and Marfo-Yiadom (2011) also found that banks that pay dividend increase their performance. Amidu and Abor (2006) studied factors influencing dividend payout ratios of registered companies. They reported that profitability, cash flow, and taxes were directly related to payout ratio, while growth and risk were inversely related to payout ratio.

Indeed, the Ghanaian economy appears to be performing well. Real Gross Domestic Product (GDP) growth increased from 7\% in 2008 to $14.2 \%$ in 2011. The relatively high real GDP growth rate in 2011 was due to improvement in the export of cocoa, gold, and oil (Institute of Statistical, Social and Economic Research [ISSER], 2012). But in 2012, real GDP declined to 7.2\% (Ghana Statistical Service [GSS], 2006-2012) and to 3.98\% by 2014. It appears that the performance of the economy depends on the export sector which tends to be unstable. In fact, decline in real growth impacts negatively on consumption and employment rate. Thus, the Ghana Stock Exchange market becomes vital to growth and development because it is an instrument of capital mobilization. Certainly, more capital mobilization will provoke more investment in Ghana. More investment will increase not only real GDP but also consumption; more jobs will be created for both skilled and unskilled labour in the country. 
In this regard, further investigation into the impact of dividend policy on the wealth of stockholders of companies registered on the Ghana Stock Exchange is justified. This paper is expected to aid managers of businesses and policy makers to identify the major factors influencing the wealth of stockholders and thus lead to policies that will attract many investors both locally and externally to invest in Ghana.

\section{Review of Past Studies}

Studies about the impact of dividend policy on the wealth of stockholders are many (Friend \& Puckett, 1964; Kumar \& Mohan, 1975; Brigham, 1995; Amidu, 2007; Salih, 2010; Mohammad, 2013; etc). Friend and Puckett (1964) examined the impact of dividends and retained profits on stock prices. Using three industries, Friend and Puckett (1964) showed that dividends have greater impact on stock prices than that of retained profits. In a study by Dhanani (2005), the author reported that dividend policy is significant in stock price measurement. Dhanani (2005) argued that a company's dividend policy can influence at least one of the defectiveness in the real world such as information asymmetry, agency problems, taxes and transaction costs which in turn, appreciate the stock price.

In South India, Azhagaiah and Priya (2008) studied the impact of dividend policy on stockholders' value using a sample of twenty-eight chemical companies listed on the Bombay Stock Exchange (BSE). Multiple and stepwise regression was applied to the data which covered the period 1997-2006. Azhagaiah and Priya (2008) found that dividend policy affects the value of stockholders in organic chemical industry while those in inorganic chemical industry are not affected by dividend policy.

Similarly, Khan (2009) studied the influence of cash dividends and reserved earnings influence on market value of companies registered on the Dhaka Stock Exchange (DSE) for the period 2000 to 2006. The study revealed that both cash dividends and reserved profits have direct and significant association with the market price of the firm. However, reserved profit has lesser influence on stock market price as compared to cash dividend.

In 2010, Salih analysed the correlation between dividend policy and the firm market price. Salih (2010) found that dividend policy has positive and significant association on the market value of the firm. A study by Joshi (2011) examined how dividend policy relates to stock prices in Nepal. Current market price of stock was the dependent variable while dividend of a stock, retained earning of a stock, previous price earnings ratio, and previous market price of a stock were the exploratory variables for the study. He found that both dividend of a common stock and retained earning per stock influence stock market prices of banking and non-banking sectors. It was additionally discovered from his study that dividend of a stock has dominant influence on stock market prices compared to retained profit.

Gul, Sajid, Razzaq, Iqba, and Khan (2012) investigated the correlation between dividend decision and stockholders value in Pakistan. Gul, et al. used secondary data on 75 companies listed on Pakistan and Karachi Stock Exchange during the period 2005 to 2010 for the analysis. Market price per stock is the proxy for measuring stockholders value, while dividend of a stock measures dividend policy. It was found from the study that dividend policy influences the value of stockholders.

Zakaria, Muhammad, and Zulkifli (2012) examined the effect of dividend decision on stock value variation in construction and material companies in Malaysia. Zakaria et al. (2012) used 183 companies comprising 106 material and 77 construction companies for the period 2005-2010. The dependent variable was stock price volatility; dividend yield, dividend payout ratio, leverage, growth, size, and earnings changes constituted the explanatory variables. It was found that dividend yield has direct influence on stock price fluctuations.

Mohammad (2013) studied the effect of dividend policy on value creation for stockholders in the sugar industry of Pakistan. Out of the 36 listed sugar companies on Karachi Stock Exchange, 33 were selected for the study for the period of 6 years from 2006-2011. Mohammad (2013) found that dividend of a stock, earnings of a stock, previous market price of a stock, and previous price earnings ratio influence market price of a stock. Therefore, dividend policy is said to have impact on stockholders' value creation in the sugar industry of Pakistan.

In Sub-Sahara Africa scores of studies have been conducted on dividend policy. In 2007, Amidu studied the relationship between dividend policy and the performance of firms listed on the GSE using ordinary least square. Amidu (2007) found that dividend policy has positive and significant association with performance of firms. The findings suggest that the profitability of the firm is influenced when there is a policy in place to pay dividend by firms listed on the GSE. In a related study, Agyei and Marfo-Yiadom (2011) examined the influence of dividend policy on the performance of commercial banks in Ghana. Panel analysis was employed on the data for the period 1999-2003. The results revealed that banks paying dividend performed better than those not paying dividend.

In a study of Uwuigbe1 et al. (2012), they assessed the determinants of stock prices in Nigeria using regression 
analysis on thirty (30) listed firms on Nigeria Stock Exchange (NSE). They found that there is a significant positive relationship between firms' dividend payment and the stock market price.

AITroundi and Milhem (2013) investigated the linkage between cash dividends, reserved profits, and stock market values of companies enlisted on the Amman Stock Exchange. They discovered from their study that cash dividend as well as reserved profits impact the stock market values of firms on the Amman Stock Exchange (ASE). The outcome of this study supports previous studies such as Nishat (1992), Pradhan (2003), and Khan (2009). AITroudi and Mihem (2013) further found that the coefficient of dividend of a stock is greater than that of reserved profit of a stock, meaning that stockholders of firms on ASE prefer cash dividend to retained earnings.

In 2005, Uddin and Chowdhury studieded the linkage between dividend payment and stock market price of firms registered on the Dhaka Stock Exchange (DSE). They reported that dividend does not improve stock market price, the stock market price rather reduces around $20 \%$ when it is thirty days to the declaration of dividend to thirty days after declaration of dividend. Their outcomes supported the irrelevant dividend hypothesis.

Adefila, Oladapo, and Adeoti (2013) studied the relationship between dividend payment and stock market price of firm in Nigeria. They found that there is no correlation between dividend payment and stock price of firms listed on the Nigeria Stock Exchange. According to them, stock prices are regulated by the Security and Exchange Commission, although Nigerian listed firms do have a dividend policy which depends on earnings, the trend is inconsistent and not proportionate.

Based on the discussion above, it is obvious that studies on the effect of dividend policy on wealth of stockholders have been inconclusive. On the one hand some researchers (Amidu, 2007; Khan, 2009; Salih, 2010; Gul et al., 2012; Oyinlola, \& Ajeugbe, 2014) found significant and positive relationship between dividend policy and the market price of firms (wealth of stockholders). Others studies have also reported that dividend policy has no impact on the wealth of stockholders (Uddin \& Chowdhury, 2005; Adefila et al., 2013).

\section{Method, Data and Variable Description}

\subsection{Method}

To investigate the effect of dividend policy on the wealth of stockholders of companies registered on the Ghana Stock Exchange, this paper used panel data analysis for the period 2005-2011. According to Gujarati (2003) panel analysis combines time series with cross sectional data which can enhance the quality and quantity of data in a way that would be impossible using only one of these dimensions.

The basic model for panel regression has the form:

$$
Y_{i t}=\beta_{0}+\beta_{1} X_{1 i t}+\ldots \beta_{k} X_{k i t}+\varepsilon_{i t}
$$

Specifically, we specify the model as:

$$
M P S_{i t}=\beta_{0}+\beta_{1} D P S_{i t}+\beta_{2} R E P S_{i t}+\beta_{3} F L E V_{i t}+\beta_{4} P E R_{i t}+\varepsilon_{i t}
$$

Where, MPS is market price per stock, DPS is dividend per stock, REPS is retained earning per stock, FLEV is financial Leverage, PER is price earnings ratio, $\beta_{1}-\beta_{4}$ are coefficients, $\beta_{0}$ is the intercept, and $\varepsilon_{i t}$ is the error term. The subscript ' $i t$ ' indicates the firm and time effect.

There are many types of panel data models (Gujarati, 2003; Johnson, 1994; Yaffee, 2005). But for the purpose of this paper we estimated the pooled, random effect, and the fixed effect models.

\subsection{Data}

Secondary data are used for analysis and comprises annual reports of twenty-five (25) companies out of the thirty-five (35) companies listed on the Ghana Stock Exchange for the period 2005-2011. The data were collected from income statements, statement of financial position, cash flow statements, and the notes to the various accounts for in-depth explanation. The selection of 25 companies was based on two factors: First, the company has paid dividend at least once a year during the study period and second data on the firm are available.

\subsection{Variable Description}

This section deals with the description of variables (dependent and independent) used in this study.

The dependent variable is the wealth of stockholders and the market price of a stock (MPS) was used as proxy for measuring the dependent variable. Previous studies have also used MPS as measurement of the wealth of stockholders (Khan, 2009; Salih, 2010; Mohammad, 2013; Onyilola \& Ajeigbe, 2014). The MPS is the end of fiscal year market price of a common stock. At any point in time investors estimate the price (value) of a stock based on the anticipations of future performance. When the future expectations are favourable, price of the stock 
will appreciate and the price will fall when expectations of the future performance are unfavourable.

The independent variables include dividend per stock, retained earning per stock, financial leverage, and price earning ratio. Dividend per stock (DPS) and retained earning per stock (REPS) are used to measure dividend policy.

Dividend per stock (DPS) is the amount paid as dividend on an ordinary stock. It is usually proposed by management at annual general meeting for approval by the ordinary stockholders. In this paper dividend per stock is obtained by dividing cash dividends paid to common stockholders by the number of equity stocks issued by the company. Dividend per stock (DPS) is expected to have direct relationship with market price of common stock. Dividend represents a motivation for investing in a particular stock, mainly when the return on that particular security is larger than those obtainable from other alternative form of investments. It is hypothesized that investors will pay a high price for issued dividend-paying stocks and vice versa. Khan (2009), Joshi (2011), and AITroudi \& Mihem (2013) have also used DPS as explanatory variable in their studies.

Retained earning per stock (REPS) is the proportion of earning per stock attributable to equity stockholders held in the business for reinvestment. REPS is measured by subtracting dividend per stock from earning per stock. REPS is expected to be positively correlated with market price of common stock (MPS). This is because retained earning is meant to be reinvested in profitable project that will yield more returns, a high retained earning per stock will increase the market price of stock, and low retained earning per stock will decrease the market price of common stock. Salih (2010), Mohammad (2013), and Onyilola and Ajeigbe (2014) have also used REPS as an explanatory variable.

Financial leverage (FLEV) measures how much of the assets of the firm are funded by debt. It is measured by dividing total debt by total assets for each accounting year. Amidu (2007) and, AITroudi and Mihem (2013) have also used financial leverage as explanatory variable. We hypothesize that increase in financial leverage will bring about decline in market price of stocks.

Price earning ratio (PER) measures the confidence that the market has in the firm to earn more income in future considering its present earnings. Mohammad (2013) also used price earning ratio as explanatory variable. It is obtained by dividing market price of common stock (MPS) by earning per stock (EPS) of common stock. Price earning ratio is expected to have direct correlation with market price of ordinary shares.

\section{Results and Discussion}

\subsection{Descriptive Statistics}

Table 1 presents the descriptive statistics and the figures indicate that mean market price of stocks of the selected companies is 1.0744 and the standard deviation is 1.71504 . These figures suggest that the average market price of stock is high, and there is high variation in terms of market price of a stock among companies listed on the GSE over the seven-year period of study.

Table 1. Descriptive statistics

\begin{tabular}{cccccc}
\hline Variable & Number of Obs. & Minimum & Maximum & Mean & Std. Deviation \\
\hline MPS & 174 & 0.02 & 10.57 & 1.0744 & 1.7150 \\
DPS & 174 & 0.00 & 0.71 & 0.0516 & 0.1142 \\
REPS & 174 & -0.31 & 1.38 & 0.0867 & 0.2174 \\
FLEV & 174 & 0.01 & 1.23 & 0.6320 & 0.2598 \\
PER & 174 & -121.74 & 141.56 & 12.7618 & 24.3488 \\
Valid N (listwise) & 174 & & & & \\
\hline
\end{tabular}

For dividend per stock (DPS) the values are within the range of 0.00 to 0.71 ; that is, some companies did not pay dividend at all, while other companies paid moderate amount of dividend. Retained earning of a stock (REPS) has a minimum value of -0.31 and the highest value of 1.38 . This suggests that some companies suffered losses and did not retain income at all while others retained greater portion of their earnings. It has a mean value of 0.0867 , indicating that on the average REPS is low and the standard deviation is 0.2175 , indicating high variation.

Price earning ratio (PER) has a minimum value of -121.74 and maximum value of 141.56 . The -121.74 figure suggests that stockholders of some companies listed on the Ghana Stock Exchange have lost confidence in the future performance of the companies looking at their present earnings, whilst the 141.56 implying that stockholders of those companies have great confidence in the future performance of the companies based on their 
current earnings. The average price earning ratio of selected companies is 12.7618 which is very encouraging.

\subsection{Multi-Collinearity Test}

Tolerance (TOL) and variance inflation factor (VIF) were used to test for multi-collinearity and the results are shown in Table 2.

Table 2. Collinearity statistics

\begin{tabular}{lcc}
\hline Variable & Tolerance & Variance Inflation Factor \\
\hline DPS & 0.9983 & 1.00 \\
REPS & 0.9780 & 1.03 \\
FLEV & 0.9839 & 1.02 \\
PER & 0.9841 & 1.02 \\
\hline
\end{tabular}

Table 2 reveals that the TOL levels for the regressors range from 0.9780 to 0.9983 , which are above 0 and close to 1. Therefore, from the TOL test, there is no multi-collinearity in the regression model. Additionally, VIF for the independent variables range from 1.00 to 1.03 which are less than five (5) recommended by Berenson et al. (2009), therefore from the VIF test, multi-collinearity poses no serious concern with the set of explanatory variables within the regression model.

The results suggest that the variables of interest (dividend per stock and retained profit per stock) and the control variables are good predictors of market price of stocks of companies enlisted on Ghana Stock Exchange.

\subsection{Hausman Test}

The Hausman test (1978) was used to choose between fixed effect and random effect models. The results are shown in Table 3.

Table 3. Results of Hausman test

\begin{tabular}{lcc}
\hline Test Summary & Chi-sq Statistic & Prob. \\
\hline Hausman & 21.66 & 0.0002 \\
\hline
\end{tabular}

From Table 3 the estimated Probability value is 0.0002 . This figure is below 0.05 and thus suggests that the fixed effect model is a better choice. The import of this result is that there are both individual firm effect and time effect in the determination of stocks market prices.

\subsection{Analysis of Regression Results}

Tables 4, 5, and 6 reports the regression results for the three panel models (Fixed, Random, and pooled Effects). Results for all the models are roughly similar but following the Hausman test results, the analysis is based on the fixed effect report. Results for the fixed effect model indicate that the adjusted R-squared value is 0.6160 , thus suggesting that the explanatory variables explain roughly $61 \%$ of changes in the dependent variable - market price of stocks (MPS).

Table 4. Fixed effect regression results - dependent variable is MPS (174 Obs.)

\begin{tabular}{cccc}
\hline Variable & Coef. & Std. Err. & Prob. \\
\hline DPS & 5.883 & 1.168 & 0.000 \\
REPS & 1.082 & 0.492 & 0.029 \\
FLEV & -0.226 & 0.404 & 0.576 \\
PER & 0.005 & 0.003 & 0.080 \\
-CON & 0.758 & 0.276 & 0.077 \\
R-Squared: & 0.8162 & Adjusted R-Squared: & 0.6160 \\
\hline
\end{tabular}


Table 5. Random effect regression results - dependent variable is MPS (174 Obs.)

\begin{tabular}{cccc}
\hline Variable & Coef. & Std. Err. & Prob. \\
DPS & 8.987 & 0.987 & 0.000 \\
REPS & 1.263 & 0.434 & 0.004 \\
FLEV & -0.484 & 0.358 & 0.176 \\
PER & 0.005 & 0.003 & 0.070 \\
-CON & 0.739 & 0.273 & 0.007 \\
R-Squared: & 0.8252 & Adjusted R-Squared: & 0.6239 \\
\hline
\end{tabular}

Table 6. Pooled effect regression results - dependent variable is MPS (174 Obs.)

\begin{tabular}{cccc}
\hline Variable & Coef. & Std. Err. & Prob. \\
DPS & 11.253 & 0.708 & 0.000 \\
REPS & 1.561 & 0.377 & 0.000 \\
FLEV & -0.842 & 0.313 & 0.080 \\
PER & 0.007 & 0.003 & 0.040 \\
_CON & 0.803 & 0.221 & 0.000 \\
R-Squared: & 0.6252 & Adjusted R-Squared: & 0.6163 \\
\hline
\end{tabular}

From the regression results all the explanatory variables have the expected signs. DPS and REPS are statistically significant at the $1 \%$ and $5 \%$ significance levels respectively. The coefficient for PER is also significant but the significance level looks weak i.e. $10 \%$.

The report shows that the DPS variable is consistent with standard findings and suggests that there is positive coefficient (5.883) and statistically significant (0.000) association between dividend per stock and market price of a stock at $1 \%$ level of significance. This finding suggests that the variable of interest, dividend per stock does influence the market price of the stock of companies registered on the GSE. This finding is consistent with some past studies (Khan, 2009; Salih, 2010; Joshi, 2011; Mohammad, 2013). These studies reported positive and significant association between dividend per stock and the market price of a stock. In contrast, our finding does not appear to support Adaramola (2012) and Adefila et al. (2013).

As regards retained earning per stock (REPS) Table 4 indicates that it has a positive and significant impact on market price of stock (MPS) at 5\% level of significant. This suggests that retained earning per stock and the market price of stock are positively correlated. This finding is in line with Khan (2009), Salih (2010), Joshi (2011), AITroundi and Milhem (2013). These studies found that retained earning per stock has positive and significant relationship with the market price of stock.

Additionally, results in Table 4 reveal that the PER coefficient is positive (0.00481) and statistically significant. However, as indicated earlier the significant level is weak-i.e. 10\%. This weak significance level notwithstanding our finding shows that price earning ratio has positive influence on market price of stock. Our finding buttresses Mohammad (2013) who showed that price earning ratio has positive but insignificant relationship with the market price of a stock.

On financial leverage (FLEV) the results reveal that it has negative but statistically insignificant association with market price per stock (MPS). This finding is inconsistent with previous study. For example AITroundi and Milhem (2013) found that financial leverage has positive but statistically insignificant relationship with the market price of a stock.

\section{Conclusion and Policy Implication}

The major objective of the research was to examine the impact of dividend policy on the wealth of stockholders of companies enlisted on the Ghana Stock Exchange. Secondary data obtained from the annual reports of twenty five companies registered on the GSE were used. Fixed-effect model was applied to data covering the period 2005-2011. Market price per stock was used as proxy for measuring the wealth of stockholders. Dividend per stock and retained earning per stock measured dividend policy. The paper also used financial leverage and price earning ratio as control variables.

Our regression results in Table 4 show that there is positive and significant association between dividend payments and stock market price of companies enlisted on the Stock Exchange of Ghana. Another significant finding is that retained earnings and price earnings ratio are positively correlated with stock market price of companies. The 
result also reveal that dividend per stock has greater significant positive impact on the stock market price of companies listed on GSE compared to retained earning per stock.

Indeed, our findings have significant policy implications for Ghana and Sub-Sahara Africa in general. Firms listed on the Ghana Stock Exchange should adopt optimal trade-off policy between dividend payments and retained earnings that would improve stockholders wealth in terms of dividend payment and capital appreciation.

\section{References}

Adaramola, A. O. (2012). Information Content of Dividend: Evidence from Nigeria. Developing Country Studies, 2(2), 74-83. Retrieved from http://www.iiste.org

Adefila, J. J., Oladipo, J. A., \& Adeoti, J. O. (2013). The Effect of Dividend Policy on the Market Price of Shares in Nigeria: Case Study of Fifteen Quoted Companies. Retrieved from http://www.scribd.com/doc/132398617/14-the-Effect-of-Dividend-Policy-1

Agyei, S. K., \& Marfo, E. Y. (2011). Dividend policy and banks performance in Ghana. International Journal of Economics and Finance, 3(4). http://dx.doi.org/10.5539/ijefv3n4p202

AITroundi, W., \& Milhem, M. (2013). Cash dividends, retained earnings, and stock prices: Evidence from Jordan. Interdisciplinary Journal of Contemporary Research in Business, 4(12), 585-599.

Amidu, M. (2007). How does dividend policy affect performance of the firm on Ghana Stock Exchange? Investment Management and Financial Innovations, 4(2), 103-112.

Amidu, M., \& Abor, J. (2006). Determinants of dividend payout ratios in Ghana. The Journal of Risk Finance, 7(2), 136-145. http://dx.doi.org/10.1108/15265940610648580

Azhagaiah, R., \& Sabari, P. (2008). The impact of dividend policy on shareholders wealth. International Research Journal of Finance and Economics, 20, 180-187.

Berenson, M. L., Levine, D. M., \& Krehiel, T. C. (2009). Basic business statistics: Concepts and application. Upper Saddle River: New Jersey, Pearson Prentice Hall.

Dhanani, A. (2005). Corporate dividend policy: The view of British financial managers. Journal of Business Finance and Accounting, 32, 1625-1672. http://dx.doi.org/10.1111/j.0306-686X.2005.00643.x

Friend, I., \& Puckett, M. (1964). Dividends and stock prices. American Economic Review, 54(5), 656-682.

Ghana Companies Code. (1963). Act 179.

Ghana Stock Exchange. (2010). Fact book, Ghana: Accra. Retrieved from http://www.gse.com.gh

Gujarati, D. N. (2003). Basic econometrics. Boston, McGraw- Hill.

Gul, S., Sajid, M., Razzaq, N., Iqba, M. F., \& Khan, M. B. (2012). The relationship between dividend policy and shareholder's wealth. Economics and Finance Review, 2(2), 55-59.

Hausman, J. (1978). Specification test in econometrics. Econometrical, 46, 1251-1273. http://dx.doi.org/10.2307/1913827

Joshi, A. (2011). Effect of dividends on stock prices in Nepal. NRB Economic Review.

Khan, S. H. (2009). Determinants of share price movements in Bangladesh: Dividends and retained earnings. A Thesis for MSc. in Business Administration, Bangladesh: School of Management, Blekinge Institute of Technology.

Kumar, S., \& Mohan, M. (1975). Share prices in India. Indian Economic Journal, 23, $23-27$.

Mohammad, S. S. (2013). The effect of dividend policy on shareholders' wealth: A study of sugar industry in Pakistan. Global Journal of Management and Business Research, 13(7).

Oyinlola, O. M., \& Ajeigbi, K. B. (2014). The impact of dividend policy on stock prices of quoted firms in Nigeria. International Journal of Economics, Commerce, and Management, 2(9).

Salih, A. A. (2010). The effect of dividend policy on market value: UK empirical study. Doctoral Thesis, Durham University. Retrieved from http:// etheses.dur.ac.uk/556/

Saunders, M., Lewis, P., \& Thornhill, A. (2007). Research methods for business students. Harlow: FT Prentice Hall, Industry in Pakistan.

Uddin, M. H., \& Chowdhury, G. M. (2005). Effect of dividend announcement on shareholders' value: Evidence from Dhaka Stock Exchange. Journal of Business Research, 1. 
Uwuigbe1, U., Olowe, O., \& Godswill, A. (2012). An Assessment of the Determinants of Share Price in Nigeria: A Study of Selected Listed Firms. Acta Universitatis Danubius, 8(6), 78-88.

Zakaria, Z., Muhammad, J., \& Zulkifli, A. H. (2012). The impact of dividend policy on the share Price volatility. International Journal of Economics and Management Science, 2(5), 1-8.

\section{Copyrights}

Copyright for this article is retained by the author(s), with first publication rights granted to the journal.

This is an open-access article distributed under the terms and conditions of the Creative Commons Attribution license (http://creativecommons.org/licenses/by/3.0/). 